\title{
COLONIAL BOUNDARIES OF AFRICA: THE CASE OF ETHIOPIA'S BOUNDARY WITH SUDAN
}

\author{
Dr. Wondwosen TESHOME, B. University of Vienna, Department of \\ Anthropology, Austria, wonteslm007@gmail.com
}

\begin{abstract}
The aim of this paper is to study the merits and the demerits of colonial boundaries in Africa by using the Ethiopia-Sudan boundary as a case study. The paper tries to examine how the existing boundary between the two countries came into being in the early $20^{\text {th }}$ century. The present-day boundary between Ethiopia and Sudan is principally the result of the 1902 and 1907 Anglo-Ethiopian delimitation treaties which were demarcated in 1903 and 1909 respectively. At present, there is confusion and controversy in Ethiopia, particularly, after the exposure of the alleged "secret" re-demarcation deal between the current governments of Ethiopia and Sudan that resulted, according to various media reports, in the ceding of huge Ethiopian border land to Sudan along their common border. This paper explores the historical background of the boundary conflict and gives an insight to the current boundary problem between Ethiopia and Sudan.
\end{abstract}

Key words: Africa, Anglo-Abyssinia, Boundary, Ethiopia, Haile Selassie I, Major Charles Gwynn, Menelik II, Sudan.

\section{INTRODUCTION}

Ethiopia and Sudan share a very long boundary of $1600 \mathrm{~km}$ length. Apart from their relations as neighbors, Ethiopia and Sudan have many common features. As Yacob (2007: 193) noted, the term "Ethiopia" is a Greek word for "dark" or black". Similarly the term "Sudan" is an Arabic word for "dark" or "black". Tribes such as Nuer, Anwak and Berta live in both Ethiopia and Sudan along the border areas. Many rivers from Ethiopia such as Atbara, Blue Nile (Abay), Mereb and Sobat flow to Sudan. The Ethiopia-Sudan border has two distinct marks. From the Eritrean border to Blue Nile River (where the two regions of Ethiopia, Tigray and Amhara lie) the international boundary manifests a genuine ethnic divide. In this part of the international border no major tribes live on both 
sides of the border. In the second part of the border that stretches from the Nile River to the Ethiopia's border with Kenya where Ethiopian regions such as the Beni Shangul Gumuz, Gambella, and the SNNP (Southern Nations, Nationalities, and Peoples) are located many tribes live on either side of the border. Young (Young 2007: 17) describes the border population as follows:

"From the Eritrean border down to just north of the Blue Nile River, the international boundary represents a genuine ethnic divide with only a handful of small pastoralist tribes traversing the two countries. No major tribes live on both sides of the border. From the Blue Nile south to the border with Kenya, however, many tribes live on either side of the frontier, most notably the Berta, Anuak, Nuer, Mursi, Murle, and Yangatum; the Gumuz and Hamer are based in Ethiopia but also cross the border area."

In the second half of the $19^{\text {th }}$ century and in the first half of the $20^{\text {th }}$ century, the British, representing their colonies (i.e., Sudan, Kenya and the British Somaliland) signed various treaties with independent Ethiopia to demarcate the Ethiopia-Sudan, Ethiopia-Kenya and Ethiopia-British Somaliland boundaries. This paper attempts to examine the various Anglo-Ethiopian agreements and treaties concerning the demarcation of the Ethiopia-Sudan boundary.

The boundary between Ethiopia and Sudan is very important in the political history of Ethiopia particularly starting from the $19^{\text {th }}$ century. This is because, Quara, the birth place of Theodros ${ }^{1}{ }^{1}$, is located along the border. Secondly, it was at Metema along the border between Ethiopia and Sudan that Emperor Yohannes (r. 1871-1889) died fighting against the Dervish of Sudan in 1889. Thirdly, in 1941, Emperor Haile Selassie I (r.1930-1974) returned to Ethiopia from his exile in England to fight the Italians together with the British forces by crossing the Ethiopia-Sudan border and hoisted the Ethiopian flag at the place called Omedla, along the border with Sudan. Fourthly, many Ethiopian patriots stayed in Sudan during the military occupation of Ethiopia by Italy in 1936-1941. Fifthly, the current Ethiopian rulers, the former rebels fought and defeated the Derg (1974-1991) by the support of Sudan after waging an armed struggle for about 16 years. Therefore the border area between Ethiopia and Sudan has a very special place in the social, economic and political developments in Ethiopia. It is also important to note that even in the post 1991 period many Ethiopian opposition forces (ex., OLF, EPPF) ${ }^{2}$ use the Sudanese soil as a launching pad in their war against the current Ethiopian government.

For Akihiro (2005: 95) "the most delicate and touchiest of problems between any two countries are territorial issues." Most of the time territorial change is a painful process and it has a great impact not only upon the individuals and communities that inhabit the areas involved but also upon the international community and the states concerned (Shaw 1997). According to Dzurek (19992000), the international community views some boundary disputes as more important than others due to various reasons. The main ones include: the size 
of the disputed area, the magnitude of the antagonism of the claimants, the involvement of ethnic conflicts in the disputes area, historic animosity between the disputants, the occurrence of recent violence in the area, the weakness of the disputants and their inability to control activities on their frontiers, the size of the area involved, the number of inhabitants at risk, the resources of the dispute area, the strategic nature of the disputed area, the number of people killed in the area, the number of claimants, third party involvement, and religious differences in the disputed area.

The paper attempts to answer the following research questions:

(1) What are the merits and the demerits of African colonial boundaries?

(2) How did the successive governments of Ethiopia tackle the country's relation with Sudan?

(3) How did Ethiopia demarcate its boundary with Sudan during the colonial era?

(4) What are the consequences of the Ethiopia-Sudan colonial border?

\section{CONCEPTS AND DEFINITIONS}

Scholars of boundary studies have recently attempted to identify the conceptual differences and similarities among the terms, boundary, frontier, and border. Though most of the time these terms are considered synonyms and are used interchangeably, in the academic world attempts have been made to analyze their conceptual differences and similarities (Rankin and Schofieed 2004). Anderson (1996: 10) employed the term "frontier" to denote an international boundary, and "boundary" to designate divisions at the sub-state level. However, in order to avoid unnecessary confusion in this paper I have decided to employ these terms interchangeably.

Caflisch (2006: 2) defines international boundary as "a line dividing land territory over which states exercise full territorial sovereignty." According to Shaw (1997),

"International boundaries fix permanent lines, both geographically and legally, with full effect within the international system, and can only be changed through the consent of the relevant states. Such boundaries have important consequences with regard to international responsibility and jurisdiction."

Korkor (2001) divides boundaries into "general" boundaries, and "fixed" boundaries. In general boundary the exact line of the boundary is left undetermined, whereas fixed boundary is the one that is accurately surveyed and guaranteed. According to Smith (1995: 475-484), there are two types of borders: bona fide borders, and fiat borders. Bona fide borders are physical boundaries such as river banks, coastlines and they exist in the absence of delineating activity. In other words, they exist independently of all human cognitive acts. On the other hand, fiat boundaries are the creations of humans 
and hence involve human decision. Another scholar, Krukoski (n.d), categorizes boundaries into two: Natural (geometric), and artificial boundaries. Natural boundaries involve hydric boundaries, water courses, dry boundaries, mountain ranges etc. On the other hand, artificial boundaries are boundaries marked by monuments or boundary marks that are put over the boundary. Artificial borders are borders that "depend neither on physical characteristics nor ethnic characteristics" (Özcan 2002: 49). For Özcan (2002:50) artificial borders are the cause of many border disputes. That is why there exists a belief that "natural" boundaries are good while "artificial" boundaries are bad (Caflisch 2006:4). However, we should keep in mind that at present "there is no rule of international law under which 'natural' boundaries enjoy priority over 'artificial' ones"(Caflisch 2006:4).

As Özcan (2002: 48) and Blake (1995: 44) noted, borders are established in four stages: "'historical precedent" ("allocation"), "delimitation," "demarcation," and "characterization" ("management"). Jones (1945) also identifies four stages in boundary making. These are :"(1) political decisions on the allocation of territory (2) delimitation of the boundary in a treaty (3) demarcation of the boundary on the ground (4) administration of the boundary. "A

Brown (1994: 66) defines "allocation" as "the initial understanding between states as to their territorial claims; lines may be crudely drawn on maps, but no accurate or precise description or field survey has been attempted." "Allocation" or "historical precedent" involves the process of identifying the cultural characteristics of the people in the area and considering the previous attempts to establish a border. This phase is the cause of many border conflicts in Africa because most of the borders of former colonies in Africa lack these precedents. This stage, according to Blake (1995: 44), usually is the responsibility of diplomats, soldiers and statesmen. In Africa, particularly at the onset of colonialism in the $19^{\text {th }}$ century, European colonial countries agreed very crudely to divide Africa into sphere of influences without fighting each other. The Berlin Conference (1884) was one of the most important agreements on this aspect. Though it is the first stage of boundary making, allocation involves the use of the available maps as important sources of information. In this stage, the politicians need the support of the various teams of advisors (lawyers, historians, economists etc) and technical experts ${ }^{5}$ (in cartography, geography, geodesy, computer science etc.).

Delimitation refers to the "description of the alignment in a treaty or other written document, or by means of a line marked on a map" (Brown: 1994: 66). Krukoski (n.d.) defines delimitation as "the establishment and ratification of the treaties that deal with the subject /boundaryl. During this phase, negotiators from both countries decide, in face of the existing documentation, how is the boundary line to be traced between the two territories." Delimitation, therefore, "is essentially a political process." It is the signing and ratification of treaties on border issues. In this phase, negotiators of both sides determine the boundary line based on the existing documentation on paper (Özcan 2002:48) and the negotiators of both 
parties define the boundary in detail. For Blake (1995: 46) delimitation is the critical phase of boundary making and most of the time, it is done by a joint commission. In the early years of boundary commissions in Africa boundary commissioners used to conduct their own rough surveys. The British, for instance, established the Royal Engineer officers ${ }^{6}$ to delimit the borders of their colonies. At present, technological advances have simplified boundary delimitation. Advances in technologies such as satellite imagery give latest and accurate information about the landscape. Another up to date technology very useful for boundary delimitation is Global Positioning System (GPS). According to Blake (1995: 45), GPS

\begin{abstract}
"Is usually a simple and speedy method of positioning to within an accuracy of two metres or less if done with top quality equipment. GPS has truly revolutionised the process of boundary delimitation. Its prime use is in the location of demarcation sites after delimitation, and producing a set of boundary coordinates to be used for treaty purposes. GPS clearly enables interested parties to test the accuracy of past boundaries where these were delimited by coordinates in a treaty, and marked out on the ground in accordance with those coordinates. "
\end{abstract}

The third phase, "demarcation" involves interpreting the intentions of the delimiters on the ground. This phase is a technical or mechanical phase involving erecting monuments and sign posts (Özcan 2002:49). According to Brown (1994: 66), demarcation "is the means by which the described alignment is marked or evidenced on the ground, by means of cairns of stones, concrete pillars etc." Demarcation comes when,

"The demarcators try to interpret on the terrain the intentions of the delimiters. This is a technical phase, which can offer some difficulties of interpretation in finding on the terrain the rivers, lakes, mountains or other landmark that has served as the base for the delimitation"(Krukoski n.d).

In the demarcation process, demarcating monuments or markers are erected that define the lines of the boundary of the countries ${ }^{7}$. This stage involves records such as maps, sketches, photographs, etc (Blake 1995: 47).

The last phase is "characterization" or "maintenance". In this phase "new marks are erected in order to satisfy the necessities of the population growth along the borders" (Özcan 2002: 49). This stage is the management and administration of boundaries (Blake 1995: 47) and it is a continuous process (Özcan 2002:49). The most important problem at this stage is the difficulty for large states with long boundaries to manage and administer their borders because, usually the cost of boundary management is very high ${ }^{9}$ (Özcan 2002: 49). Boundary marks are also categorized as primary and secondary marks (Rushworth 1997:61). According to Krukoski (n.d), primary marks are erected during demarcation 
phase and the secondary marks are placed during characterization phase. International boundary dispute according to Prescott (1987) are generally of three kinds: territorial, positional, and functional. Territorial disputes occur when countries contest for large tracts of land (Blake 1995: 48). Positional disputes are disputes that usually follow boundary allocation. They usually happen before delimitation. But, sometimes, they can also occur after delimitation (Blake 1995: 48). Functional disputes arise in relation to boundaries every day management, and operation (Blake 1995: 48).

\section{COLONIAL BORDERS AND THEIR CONSEQUENCES IN AFRICA}

In the last two decades boundary problems and demarcation-related issues in Africa were the subjects of intense discussion among scholars. The main ones include: Abbink (2003), Bouquet (2003), Brownlie (1979), Englud (2003, 2002), Griffiths (1996), Konings (2005), Kornprobst (2002: 369-393), Lentz (2003), Nugent and Asiwaja (1996), Oduntan (2006), and Pratt (2006). So far, however, only scant works such as Gwynn (1937) are available on Ethiopia's border with Sudan.

Borders are imagined lines that are rarely demarcated on the ground, "demonstrating their nature as artificial, historical construction and alleged, political invention" (Brambilla n.d: 3). Borders in Africa were introduced during colonialism $^{10}$. As indicated by Bentsi-Enchill (1976), Asiwaju (1984), Jackson and Roseberg (1982), and Davidson (1992) colonial borders were created without the knowledge, consent and consultation of the African people. ${ }^{11}$ Therefore, due to their colonial origin the boundaries of contemporary Africa are usually considered arbitrary (Ajala 1983, Asiwaju 1985, Atzili 2004; Barbour 1961, Bello 1995, Brownlie 1979, Davidson 1992, Kum 1993, Nugent 1996, Nugent and Asiwaju 1996, Sautter 1982, Touval 1969). Loisel (2004: 4) characterized the African borders as follows: "Borders in Africa would be arbitrary and artificial, delineated by exogenous colonial powers with little knowledge of the local communities, dividing pre-existing and homogeneous ethnic groups and thereby stirring frustrations and conflicts."

There have been many controversies and arguments concerning the arbitrary nature of African boundaries. For Davidson (1992) the arbitrariness of the colonial borders and the dissection of ethnic groups and tribes (and even sometimes families) in the colonial era are the major causes of African conflicts $^{12}$. In other words, the ethnic wars that are caused by the arbitrary nature of African boundaries are the major causes for instability in the continent. Therefore, for Griggs (1995a, 1997) the mismatch between nations and states is responsible for the continents instability, civil war, genocides etc.

For Loisel (2004: 4) these borders are not only arbitrary but they were also the product of continental and global rivalries among European powers. Therefore, according to Loisel (2004: 4), citing Miles (1994: 68), 


\begin{abstract}
"Borders were drawn essentially according to the geopolitical, economic and administrative interests of the colonial powers, often taken into account at a global scale. The most often cited example is that of the division of the Hausaland, between today's Niger and Nigeria. The Franco-British treaties of 1904 and 1906 redrew the border in favor of the French side, in exchange for France's renunciation of fishing rights off the coast of Newfoundland" (Miles, 1994: 68).
\end{abstract}

Odugbemi (1995) and Clapham (1996) argue that everywhere borders are artificial and the case of Africa is not different from others. According to Nugent (1996) and Bach (1999), though African boundaries are arbitrary they have also advantages. Herbst (2000) has also reinforced this argument. Herbst (2000) argues that African boundaries are assets for state consolidation. For Touval (1969) and Ottaway (1999) the arbitrary nature of African boundaries has only few disadvantages. Scholars like Barbour (1961), Griffiths (1996), Bayart (1996) and Young (1996) advocate for the status quo of African colonial boundaries despite their arbitrariness because attempting to reshuffle states is more costly than the hypothetical benefits. There are also scholars who advocated for territorial reconfiguration of African boundaries (Bello 1995; Herbst 2000; Nkiwane 1993; Sambanis 1999).

Though from the start the Organization of African Unity (OAU) acknowledged the imperfections of the national boundaries of African countries (which were the by-products of Colonialism) it decided to accept the inviolability of the national boundaries in its 1964 resolution (DFID 2001:6; Atzili 2004). According to Francis Borella, cited in Wembou (1994: 16),

"Many resolutions adopted by the OAU continually strengthen the territorial foundation of the African States and their respective frontiers. Resolution A.G.H/16.1 of July 21, 1964, to cite just one, incorporates the rule of uti possidetis.' 'All the member States are committed to respect the frontiers existing at the time of their independence."

Therefore, after the disintegration of colonialism all African governments except Morocco and Somalia agreed to maintain colonial boundaries (Englebert et al Feb. 2001). ${ }^{13}$

Territorial or border disputes are one of the major causes for war ${ }^{14}$, and most of the wars and bloodsheds due to territorial disputes occurred in Africa (Griggs 1994, 1995a, 1995b). Due to the arbitrary nature of the colonial boundaries, right after the end of colonialism a border dispute has become one of the causes for conflicts in Africa as manifested in boundary disputes between Ethiopia and Eritrea (Abbink 2003, 1998; Fielding 1999: 89-97; Pearce 2000; Pratt 2006; Korkor 2001; Sodeinde 2001), Nigeria and Cameron (Dzurek 1999; 
Konings 2005; Oduntan 2006; Aghemelo and Ibhasebhor 2006; Korkor 2001; Sodeinde 2001), Ethiopia and Somalia (Hoyle 2000), Somalia and Kenya (Kromm 1967), Mozambique and Malawi (Englund 2002), Botswana and Namibia (Korkor 2001, Perry 2000), Eritrea and Djibouti (DeCapua, 11 June 2008; VOA 11 June 2008), Sudan and Egypt (Dzurek 1999-2000:83-95; Time 3 July 1995), Sudan and Kenya (Mburu 22 March 2003), Uganda and Congo DR (Mugabi 13 May 2008), Zambia and Zimbabwe (Dzurek 1999-2000:83-95), Malawi and Tanzania (Mayall 1973) and so on. In a rare instance an African country, Eritrea, had fought a border war with a non-African country, Yemen over the Hanish Islands (Dzurek 1996; Kwiatkowska 2001; Westing 1996: 201206).

Except Ethiopia which successfully fought for the preservation of its independence and territorial integrity, almost all African countries are the creation of European colonialists. Some countries in Africa such as Congo DR and Sudan got very large territory and natural resources thanks to the generosity of European pens, while other African countries were not lucky and got very small territories (E.g. Burundi, Rwanda, Swaziland, Lesotho, Gambia, Djibouti, and Equatorial Guinea) (Griggs 1997: 66).

\section{ETHIOPIA AND SUDAN: POLITICAL RELATIONS AND BOUNDARY DEMARCATION}

\subsection{The Reign of Yohannes IV and the Ethiopia-Sudan Relations}

Though many historical and archaeological evidences indicate the very long economic and political relations between Ethiopia and Sudan ${ }^{15}$, their most visible relations in the modern period started in the $19^{\text {th }}$ century. In the early $19^{\text {th }}$ Century, the Egyptians attempted to occupy Ethiopia after conquering Sudan ${ }^{16}$, and Massawa area (Eritrea). In the battle of Gundet (1875) and Gura (7-9 March 1876) Emperor Yohannes IV (r. 1872-1889) of Ethiopia repulsed the Egyptians attack. The British colonized Egypt in 1882 and assumed responsibility for her possessions including Sudan. In the mean time, the Mahdists ${ }^{17}$ of Sudan (Dervishes or Ansar) started a revolt in June 1881 against the oppressive rule of the Anglo-Egyptians and encircled the Egyptians army in Kassala ${ }^{18}$. Therefore, when Egyptian troops were besieged in Khartoum by the Mahdists the British decided to intervene. It is with this intention they sent a British negotiator Rear Admiral Sir William Hewett to the court of Yohannes to solicit the support of Ethiopian troops. A treaty was signed on 3 June 1884. The treaty is known as the Hewett treaty or Adwa treaty, after the city where the treaty was signed. In this treaty, on behalf of Egypt, Britain allowed Yohannes free import of goods, ammunition, Egyptian facilitation of the appointment of bishops, and the restoration of Bogos to Ethiopia. On his turn, Yohannes agreed to facilitate the evacuation of the besieged Egyptian troops from Kassala, Amideb and Sanhit towns of Sudan (The New York Times 25 July 1884). This action of Yohannes led to a war between Ethiopian forces and the Dervishes of Sudan (New York 
Times 20 February 1888; 17 February 1888). On 23 September 1888, Ras Alula, one of the loyal generals of Yohannes successfully fought the Mahdists led by Uthman Dinqna at Kufit (east of Kasala) (Bahru 2002: 58). In retaliation, the Mahdists invaded Asosa (in Benishangul-Gumuz region) following the footsteps of the Egyptians who had sphere of influence in the area, but were repulsed by the Ethiopian troops when they approached Najjo area (Wollega) on October 14, 1888 (Bahru 2002: 59). In the northern front, the Mahdists occupied Metema (which was evacuated by the Egyptians). King Teklehaymanot of Gojam was ordered by Emperor Yohannes to fight against the Dervishes. Teklehaymanot's army, after initial victory, was routed by the Dervishes. The Dervishes also raided Dambiya and Gondar (in Amhara region) after defeating the Ethiopian governor and the vassal of Yohannes in the area, King Teklehaymanot. In the mean time, the leader of the Dervishes, Khalifa Abdallah ${ }^{19}$, sent an ultimatum to Emperor Yohannes as claimed by Sanderson (1969: 19). The Khalifa in his ultimatum said, "...If you will do what / tell you, then I will cease to wage war against you and will instruct my army not to enter your country" (Sanderson, 1969: 19). Then, Khalifa's army invaded and sacked Gondar town. With the aim of avoiding war with the Dervishes (Since he had already faced the threat of the Italians in North Ethiopia) Emperor Yohannes, sent a peace offer to the Dervish leader. According to Sanderson (1969: 70), the emperor wrote:

"Let us not kill the poor and the harmless to no purpose, but let us both unite against our common enemies, the Europeans. If they conquer me, they will not spare you, but will destroy your country.... It is, therefore, our common interest to agree to fight and conquer them."

The Sudanese leader rejected Yohannes' peace offer and the two sides fought a decisive battle at Metema on 9-10 March 1889 culminated by the death of Yohannes. The Dervishes beheaded Yohannes' head and took it to Sudan as a trophy (Bahru 2002: 59; The New York Times 4 April 1889; 4 May 1889; Yacob 2007: 196). In the final analysis, as Rubenson (1976: 362) said, Yohannes traded "one weak enemy for two strong ones, (the Mahdist state and Italy)". Yohannes fulfilled his part of the treaty by sending an army under Ras Alula and fought the Mahdists in order to give a free passage to the Egyptian troops. On the other hand, the British failed to honor the treaty, and allowed a new power in the area, the Italians, to occupy what the Egyptians left: Massawa (Eritrea) (Bahru 2002: 54-56).

\subsection{The Reign of Menelik II (1889-1913) and the Anglo-Ethiopian Border Treaty}

After the death of Yohannes in 1889, Menelik II (r. 1889-1913) became the emperor of Ethiopia. In his early years as emperor of Ethiopia, Menelik wanted peaceful relations with Sudan. Particularly, the threat from Italy forced Menelik 
to look for potential allies in case he was forced to fight against the Italian forces who by that time increased their aggression against Menelik's empire from the north. Unfortunately, the Sudanese leader was still keeping his grudges against Ethiopia and was reluctant to forge an alliance with Ethiopia against Europeans. Therefore, Ethiopia was forced to fight the Italians alone. In 1896, at the battle of Adwa, Menelik scored a resounding victory against the Italians. The Adwa victory greatly increased the image of Menelik in the international world. Many European countries, particularly, the French, the British, the Germans etc., sent emissaries to Menelik asking for his friendship. This time, the Sudanese leader Khalifa Abdellah, was also interested to forge an alliance with Menelik. Therefore, when Menelik renewed his call for friendship with Sudan, the Sudanese leader did not waste time to accept the offer. The Khalifa sent Mohammad Othman to Menelik's court with few preconditions (Berry 1968: 8). The Khalifa requested Menelik to renounce all his relations with Europeans as a precondition to make an alliance with Sudan. Menelik rejected the precondition of the Sudan, but in 1897 both countries reached a sort of agreement to form an alliance. According to Berry (1968: 84), as a sign of friendship, Menelik secretly notified the Khalifa of the imminent invasion of Sudan by the Anglo-Egyptian forces. In return, the Khalifa withdrew his alliance with the Shaik of Benishangul ${ }^{20}$ who had been very active in resisting Menelik's over lordship. In September 1898, the Anglo-Egyptian forces led by Kitchener re-conquered Sudan and defeated the Mahdists. Only in 1956 Sudan re-gained its independence (Yacob 2007: 196).

\section{The Ethiopia-Sudan Boundary Delimitation and Demarcation Background}

The architect of the border demarcation between Ethiopia and Sudan during colonialism was Major (later General) Charles Gwynn ${ }^{21}$, an Irish explorer. Until Charles Gwynn came to the border area, the boundary between Sudan (then under Britain) and independent Ethiopia was not delimited or demarcated. As Gwynn himself (1937: 150) admitted, "Owing to their great extent, and to the obvious difficulty of policing such backward and unprofitable regions thoroughly, the frontiers have never been demarcated with the elaboration customary in most countries." Gwynn (1937: 150) listed four major problems that hindered the Ethiopia-Sudan demarcation process at that time. These were:

(1) Lack of aeroplanes and motor transport that could be useful for making reconnaissance trips and to transport supplies needed for the laborers on the scene.

(2) The shortage of food and water supplies for the laborers since few supplies were obtainable in the border district.

(3) The failure of the Ethiopian ${ }^{22}$ government to send trained and educated personnel to represent the Ethiopian side.

(4) The unwillingness of the Ethiopian government to employ Europeans to represent Ethiopia in the demarcation process ${ }^{23}$. 
Gwynn (1937: 150, 160) frankly admitted that in light of all the above factors attempting to properly demarcate the boundary "would have entailed great waste of money. "Though the British took control of Egypt and its colony Sudan in 1882, till 1902 they were not able to delimit Sudan's border with Ethiopia. In addition, for British authorities in Sudan let alone demarcating the EthiopiaSudan border, even their political control in Sudan itself was in a great danger due to the rebellion of the Sudanese people led by Khalifa, the successor of Mahdi. The Sudanese freedom fighters were able to expel the Anglo-Egyptians from Khartoum and the surrounding areas for some time ${ }^{24}$. Moreover, the British were worried that Menelik would join the Khalifa of Sudan against their interest in the area (New York Times 23 May 1897). Therefore, with this in mind, they sent a delegation known as the "Rodd Mission"25 to Addis Ababa in 1896-97; "mainly," says Gwynn (1937: 150), "to prevent the possibility of his making common cause with the Khalifa". Moreover, the British wanted a confirmation from Menelik of his recognition of "British and Egyptian territorial rights throughout the regions of the White Nile, including Kordofan and Dar Sennaar" (New York Times 7 March 1897). The Road mission was accompanied by Captain Harrington who was a British political officer in Somaliland. The Rodd mission was successful in convincing Menelik not to side with Khalifa. According to the Figaro, reported by The New York Times (22 September 1897) "the mission of James Rennell Rodd to the king of Abyssinia resulted in a promise of neutrality upon the part of king Menelik by guaranteeing the Western frontier of Abyssinia in the names of both Great Britain and the Mahdi."

The second aim of the delegation, i.e. getting Menelik's consent on border demarcation ${ }^{26}$ (which Captain Harrington was entrusted with) was not that much progressed as the British expected. In the negotiations with the Rodd Mission, the wise Menelik forced the British to give him concessions. The New York Times (12 January 1898), quoting the Birmingham Post reported:

"The treaty which James Rennell Rodd, principal secretary of the British Agency and consulate General in Egypt, negotiated with king Menelik of Abyssinia, contains a clause binding king Menelik not to allow any obstacle to emanate from Abyssinian territory with the object of blocking the Egyptian advance upon Khartoum. As a quid pro quo king Menelik secures a certain rectification of the frontier when the Khalifa is subdued."

The British re-conquered Sudan after defeating the Mahdists in 1897. The greatest fear of the British (immediately after they re-conquered Khartoum by defeating the Mahdists) was the reaction of Menelik. They thought that Menelik would march against their forces in Sudan. On this issue, the New York Times held a discussion with M. Casimir Mondon Vidailhet, the director of public education in Ethiopia (The New York Times 25 September 1898). To the question whether Menelik would march against British forces in Sudan Vidailhet responded, 
"The Emperor Menelik will certainly never take the offensive against the British......But should they attempt to conquer any territory which at present forms an integral portion of the Empire of Ethiopia that empire which represents a high degree of civilization in the Dark Continent-then they will most certainly be opposed by the army of the Negus, 300,000 strong, and capable of being increased to a considerable extent" (The New York Times 25 September 1898).

The British had also another reason to fear Menelik's military retaliation. Contrary to the expectation of Menelik, the Anglo-Egyptian forces controlled Kassala by conniving with the Italians when the Italians evacuated from the area after their defeat by Menelik's force in 1896 at Adwa. When Menelik learned that Kassala was handed over to Egyptian (Anglo-Egyptian) forces after the evacuation of the Italians, he was very much angry and mobilized his army for confrontation. ${ }^{27}$ It was reported in the New York Times (23 January 1898) that alarmed by Menelik's sudden move, the British rushed a reinforcement army to Egypt. According to the New York Times (23 January 1898), "Col. Parsons, while enroute to take over Kassala from the Italians, found king Menelik of Abyssinia in the greatest state of Wrath at the surrender to Egyptians of the town, which his Majesty regarded as part of his domain, and he was mobilizing an army, with the intention of asserting his authority."

Alarmed by the activities of Menelik's forces in the border areas the British decided to demarcate Sudan's border with Ethiopia and extend their rule in Kenya. According to Gwynn (1937: 151), "When .....early in 1889, Harrington succeeded in getting Menelik's agreement to at tentative frontier it could only be represented by a blue chalk line drawn on the map without any very definite topographical or ethnographical meaning. It did, however, recognise that Beni Shangul, a large district south of the Blue Nile above the limit of navigation, which had formerly been in Egyptian hands but which had been conquered by Menelik in 1898, should be treated definitely as having passed to Abyssinia."

During 1899 Summer Harrington went back to England with his map and the British decided to further explore the region (the border area) and "to get an idea as to how far effective Abyssinian occupation extended" (Gwynn 1937: 151). Therefore, the British prepared two teams of expedition. The first team consisting Major Austin, R.E., and Captain Bright ${ }^{28}$ from Rifle Brigade was assigned to explore the region from the Sobat South to Lake Rudolf (Gwynn 1937: 151). The second team was lead by Charles Gwynn and Lieut. Jakson R.E. This team was assigned to explore the section between the Blue Nile and the Sobat river (Gwynn 1937: 151). From Omdurman Major Austin's team was transported to the Sobat by steamer, but Gwynn's team was not able to get a steamer due to a low and falling Nile. Therefore, Gwynn's team was forced to employ native boats and made its way up the Blue Nile to Roseiles. As Gwynn 
(1937: 152) readily admitted, both teams were instructed by the British government "to pose as a semi-scientific, semi-shooting expedition, and to avoid discussing frontier questions with anyone, except possibly Abyssinian officers of some rank whom we might meet."

According to Gwynn (1937: 152), this was because, "it was obviously inadvisable to unsettle the local natives or to encourage them in any way to resist Abyssinian parties until the frontier question was settled and the Government [British] ${ }^{29}$ in a position to give them some protection."

As Gwynn (1937: 152) further narrated, they were also instructed:

"Not to enter without invitation any districts known to be occupied by Abyssinians, but we were as far as possible to ascertain the limits of such occupation and the position of Abyssinian posts. This especially applied to Beni Shangul, in which, as old Egyptian territory, our intentions might be open to suspicion."

Furthermore, the exploration teams were told "to make as good a map and to collect as much information as regards tribal boundaries and local conditions as the circumstances permitted, and to select physical features which might constitute recognisable landmarks for a frontier approximating to the blue line and to tribal limits." Gwynn's party was escorted by a small band of Sudanese army, and employed an Ethiopian interpreter called Daniel Desta (Gwynn 1937: 152). The first major task of Gwynn's party was "to ascertain the limits of the Beni Shangul District and the conditions prevailing in it" (Gwynn 1937: 153). According to Gwynn (1937: 154), ".....As the district had been definitely assigned to Abyssinia the chief problem was to ascertain its limits, especially how far the outlying hills should be included in it, and which could be taken as frontier marks."

It is interesting to note that without proper study and in the absence of Ethiopian government representatives, Gwynn's party arbitrarily decided to give the areas in the Benishangul region to Sudan. The only criterion he used to make this decision was the tribal fighting in the area. According to him, the outlying communities were living in fear due to their conflict with the people in Benishangul district (which was Ethiopian territory). He said, "I decided therefore to recommend that most of the detached hills should be included in the Sudan as this would correspond fairly well with the position of the blue line. ${ }^{, 30}$ When Gwynn's party reached Wallega province (in the present day Oromia region of Ethiopia) he met with Ethiopian officials in the area: Basha Zodi and Dejazmach Goti (Gwynn 1937: 155). The Ethiopian officials at first received Gwynn's and his party with friendly gesture and offered them supplies. However, later on, they became suspicious of their movements in the area and detained them.

On this issue Gwynn (1937: 156) said, 
"I had only gone south for two days when I was overtaken by an armed party of his men insisting that I should return to Gidami as it was said that instructions had been received from Addis Ababa that I should go no further. I did not believe that any such instructions had been given, but clearly there was a risk of my main party getting into trouble if / did not return ; so back I came."

In fact, Gwynn's party was not the only European "exploration" mission to be caught and detained in making "explorations" without the knowledge and permission of the Ethiopian government. Other earlier missions including Bottego mission, General Mangin's mission etc were caught and expelled. Concerning the detention, Gwynn (1937: 156-157) said,

"Our hold-up at Gidami was a typical illustration of the suspicion and refusal to accept responsibility which characterises all Abyssinians. Major Austin had a similar experience at Gore ; and when, during the war, I met General Mangin I was interested to hear that he also had been detained for over a month at Gidami, which thus was distinguished for having stopped three European Expeditions in the course of a few years-Bottego's, Mangin's, and my own."

After detained in Gidami (Wollega zone) for almost one month, Harrington was able to get Menelik's "all clear" letter from Addis Ababa and Gwynn's mission continued the expedition. After the end of the exploration, Gwynn and Colonel Harrington made another trip to meet Menelik in Addis Ababa to get the Emperor's concurrence in them. However, Gwynn and Harrington did not get what they wanted from the Emperor. On this issue, Gwynn (1937: 158) confessed as follows:

"Harrington and I had a number of conferences with the old Emperor at which he produced various Abyssinians and some of the Beni Shangul chiefs to check my arguments and information. Nothing, however, could be definitely settled, partly on account of the dislike of all Abyssinians to come to a definite decision, partly because both north of the Blue Nile and south of the Sobat information was still lacking."

Despite their insistence, the careful Emperor was not interested to agree with the plan of the British without properly digesting it. Therefore, Gwynn went to resurvey the Sudan-Eritrean frontier "as nothing further could be obtained from Menelik"(Gwynn 1937: 158). According to Gwynn (1937: 158), it

"Was not till the winter 1902-3, Harrington had succeeded in obtaining Menelik's signature to a frontier agreement, and the latter had expressed his willingness that I should represent both 
Governments in the task of showing the line to his frontier chiefs, and in carrying out such demarcation in detail as was essential. That meant drawing up a programme and telegraphing it to Harrington to arrange for successive Abyssinian District authorities to meet me at certain times and places in order that they should become acquainted with the position of the boundary."

Concluding his delimitation work in the Sudan-Ethiopia border, Gwynn said,

"In the Beni Shangul area it was evident that Abyssinian authority was far from well established, and the truculent slave-raiding chiefs gave some trouble. As already stated they had to be taught a lesson by the Sudan Government later on. As a result of the season's work, however, the whole frontier was perambulated from the Setit River in the north to the junction of the Pibor and Akobo Rivers in the south. Physical features marking it were pointed out and a certain number of artificial marks erected where more detail was required. I was not, however, sanguine of the permanence of the latter unless frequently visited by patrols-a somewhat unlikely event."

The fact that Gwynn single-handedly "delimited" the Ethiopia-Sudan border without the physical presence of the Ethiopian government representatives ${ }^{31}$ has created border disputes between Sudan and Ethiopia for many decades. Still now it is the cause of the on-and-off tensions between Sudan and Ethiopia. In fact, Gwynn himself has sensed this and foretold the situation as follows:

\begin{abstract}
"It was quite evident that respect for the frontier could only be enforced by adequate policing, and this was highly improbable considering the financial position of the Sudan Government, the valueless character of most of the frontier region, and the terrible depopulation of the country consequent on the Khalif 's regime and Abyssinian raiding. On the whole, however, the delimitation of the frontier provided a working basis for future dealings between the two Governments, which was about all that could be hoped for at the time."
\end{abstract}

After completing his work along Sudan-Ethiopia border, Gwynn once again was appointed as British commissioner to make a final demarcation of KenyaEthiopia Border. In order to carry out his new assignment he came back to Ethiopia in $1908-9^{32}$. Due to Menelik's illness ${ }^{33}$ the Ethiopian government was not able to appoint either a European or Ethiopian representative to delimit and demarcate the border. Moreover, the Ethiopian government was not able to instruct district officials along the Kenya-Ethiopia border to accompany or help Gwynn's new mission. Therefore, "after some months' delay it was consequently decided that "Charles Gwynn "should carry out the work without accredited Abyssinian representatives" (Gwynn 1937: 160). Gwynn's mission 
along Kenya-Ethiopia border ended simply by showing "the local tribes the frontier that the British Government were prepared to recognize."

\title{
4.3. The Reign of Haile Selassie I (1930-1974) and the Ethio-Sudan Relations
}

After Sudan achieved its independence in 1956 its relation with Ethiopia was not peaceful ${ }^{34}$. Between 1961 and 1974 there were armed groups along the EthioSudan border that fought against Haile Selassie's government mostly supported by Sudan. These include: the ELF (Eritrean Liberation Front), and the EPLF (Eritrean People Liberation Front). The Sudanese support to these armed groups was on-and-off. As young (2007: 17-18) said,

\begin{abstract}
"Support from the Sudanese state usually followed a pattern: when relations between Khartoum and Addis Ababa were positive, or there was an effort to improve them, support would decline, only to be resumed when relations deteriorated or Khartoum wanted to send a message to its neighboring regime."
\end{abstract}

The Imperial government of Ethiopia, frustrated by the Sudanese action, started to support the rebel movement in South Sudan known as "Anya Nya". This civil war which was also called the "First Civil War" in Sudanese history took place from 1955 to 1972.

\section{The 1972 Sudanese Peace Conference in Addis Ababa}

As the supporter of the South Sudan rebels Haile Selassie had the power to influence the rebels to negotiate with the Sudanese government. In 1972, he decided to invite both the rebels and the Sudanese government to Addis Ababa for negotiation and end the "first Civil war" in Sudan (Young 2007: 12). A peace conference between the Sudanese government of president Nimeri and the Southern Sudan Liberation Movement in Addis Ababa was held from 16-17 February 1972. The Sudanese government delegation was led by vice-president and Minister for Southern Affairs, Abel Alier. The rebels of the South were led by Ezboni Mindiri (Hoile, May 2002: 31). The negotiation was successful and it ended the first civil war. From 1972 until the mid-1980s relations between Ethiopia and Sudan were generally good. Even, in 1975, Sudan unsuccessfully tried to mediate the conflict between the Eritrean rebels and the Ethiopian government. However, when the Sudanese peoples Liberation (SPLA) started the socalled "Second civil war" or "Anya Nya II" (1983-2005) and appeared to challenge the central government of Sudan the relations between Ethiopia and Sudan once again became very sour.

The 1972 Ethiopia-Sudan Border Talk 
After hosting the successful mediation talks between the South Sudanese rebels and the Sudanese government Ethiopia started boundary demarcation negotiation with Sudan. According to Mburu (22 March 2003: 29), in 1972 the two countries exchanged notes concerning their boundary problems. However, "An exchange of notes between Ethiopia and Sudan failed to settle the question of the Baro salient or make arrangements to stop banditry and establish peaceful coexistence among the pastoral people." The 1972 Ethiopia-Sudan talk, "fell short of a viable long-term solution inasmuch as it did not redefine where the boundary should run over the Baro salient"(Mburu 22 March 2003: 31).

\section{CONCLUSION}

International boundaries that are clearly defined and well-managed are very important for good international relations, national and local security, efficient local administration and for using natural resources efficiently (Pratt 2006). According to ICG (4 April 2002: i-ii),

"The failure to resolve border issues prevents neighbors from normalizing relations and dealing with pressing social and economic issues. Thus it is important that any territorial differences be resolved on a mutually acceptable basis in accordance with the standards of international law and practice."

As Bahru (2002: 111-113) noted, "The delimitation of the boundaries between Ethiopia and the surrounding colonies was dictated mainly by the colonial powers' apprehension of the expansive potentialities of post-Adwa Ethiopia." The first boundary that was delimited was between Ethiopia and the French Somaliland (Djibouti). It was delimited on 20 March 1897. In the same year, Ethiopia's boundary with the British Somaliland was delimited. Then, in the treaty between Ethiopia and Italy on 10 July 1900, Eritrea was separated from Ethiopia. On 15 May 1902 Ethiopia signed a treaty with the British over its border with Sudan. This treaty was territorially advantageous to the British. This treaty gave Gambella to the British and guaranteed the British's hydraulic interests at Lake Tana. In 1907, Ethiopia's boundary with the British East Africa (Kenya) was delimited. In 1908, Ethiopia's boundary with the Italian Somaliland was delimited (Bahru 2002: 113). According to Bahru (2002: 114), all the boundary delimitations which Ethiopia made with the colonialists who used to rule Ethiopia's neighbors had the following problems:

"Firstly, delimitation on the map was not always followed by demarcation on the ground. The long boundary with Sudan was only partially demarcated. The boundary with British Somaliland came to be demarcated only in the 1930s..... Secondly, the absence of effective administration in the frontiers regions made the boundary delimitation little more than a cartographical exercise. The Southern and South Western boundaries were constantly 
violated by trans-frontier raids and incursions. In a sense, this was the frontier peoples' way of nullifying boundary agreements which were concluded without taking cognizance of their needs for seasonal movements of their flocks and for ethnic Unity."

In the past, particularly, during the reign of Haile Selassie I (1930-1974) Ethiopia as a dominant regional power in East Africa faced no serious challenges from the neighboring countries though Somalia and Sudan were occasionally creating border disputes. For instance, while Kenya was a British colony the British claimed an area called Gadaduma along the Ethio-Kenya border which was under Ethiopia's administration. This border dispute was not settled when Kenya achieved independence in 1963. After initial hesitation, Kenya acknowledged Ethiopia's ownership over Gadaduma in the 1970 negotiation. Kenya decided to accept Ethiopia's ownership over the disputed land because it wanted good relation with the then strong Ethiopia which was ruled by world class statesman, Emperor Haile Selassie, rather than provoking and picking up a fight (Nordquist 2002). This is because, as Nordquist (2002:10) said, sometimes "the need for good relations with a neighbor outweighed particular claims of one of the parties. "According to Nordquist (2002: 10),

"For Kenya it was more important to obtain a positive security relationship with Ethiopia, against Somalia, than to change certain aspects of the boundary. The changing conflict system for Kenya, going from British rule to independence, which made security concerns prominent for the then newly independent state, caused a shift in priorities vis-à-vis Ethiopia, which had not undergone a similar change of international status."

On the other hand, Somalia, which had a border conflict with Ethiopia, followed a different approach to solve its border problem: confrontation. Particularly, after the coming to political power of Said Barre in 1969 the direct confrontation with Ethiopia in the final analysis led to the collapse of Somalia as a nation in 1989 (Nordquist 2002: 22).

In the last few months particularly, in May-June 2008 the disclosure of the ongoing "secret" negotiations between Ethiopian government officials and the Sudanese government has created uproar in Ethiopia (Deutsche Welle 08-052008; VOA 05 June 2008) ${ }^{35}$. Many Ethiopian opposition groups and Ethiopian Diasporas have condemned this secret deal in which, according to the media reports $^{36}$, the Ethiopian government has agreed to re-demarcate the EthiopiaSudan boundary and ceded many Ethiopian lands to Sudan. Whether these allegations are true or not, we will come to know in the near future when the dust settles. But, in principle boundary demarcation should be transparent and should be ratified according to the legal procedures of both countries. As border disputes are one of the major causes for conflicts among countries, recently the ICG (4 April 2002: iii) has proposed a number of principles that should be considered in any boundary demarcations. The major ones include: Unilateral 
border demarcations should be stopped; all demarcations should be transparent; official joint commissions should be established to facilitate demarcations; the local population should be consulted; visa requirements should be simplified to facilitate border crossing procedures; consulates should be opened in border cities; border guards should be trained in border and visa procedures; border guards should be trained to stop or discourage corruption among them and customs authorities, and to prevent harassment of travelers; map archives should be open; regional governors along the border should be granted a relative free hand to deal with the Social concerns of local populations in the disputed areas; NGOs should be allowed to engage in dispute mediation along the border; ethnic minorities in border area should be protected; and boundary should be ratified according to the country's legal procedure.

\section{ENDNOTES}

(1) The Ethiopian emperor who initiated the re-unification process of the country. He ruled the country from 1855 to 1868 and died fighting against the British at Maqdalla in 1868.

\section{(2) OLF (Oromo Liberation Front); EPPF (Ethiopian Peoples Patriotic Front)}

(3) It was Stephen Jones who outlined the "traditional" four stages of boundary making in 1945. However, as Pratt (2006) noted the four stages (i.e.delimitation, demarcation, maintenance and management) should not be seen as totally independent processes. In many cases they overlap.

(4) On the other hand, Prescott (1979) identifies only three stages in boundary making: allocation, delimitation and demarcation.

(5) Ron Adler calls the politicians and their advisers as "boundary architects" and the technical specialists as "boundary engineers" (Blake 1995: 45).

(6) As stated elsewhere in this paper, Charles Gwynn who delimited and demarcated Ethiopia's border with Sudan was employed by the Royal Engineers Officers.

(7) Blake (1995: 46) argues that "agreements are........perfectly valid without demarcation."

(8) As Rushworth (1997:61) emphasized "delimitation" requires the arts of diplomacy, while "demarcation" is a mechanical process. In short, delimitation is drawing a line on the map while demarcation is drawing a line on the ground.

(9) This is particularly true in poor countries like Ethiopia and Sudan. 
(10) Loisel (2004: 4) argues that in 1990 almost $87 \%$ of African borders were inherited from colonial era.

(11) Foucher (1991: 202) claimed that by 1991, 41\% of African border had never been demarcated.

(12) On the other hand, Asiwaju and Nugent (1993) criticized the perception that claims African ethnic conflicts are caused by irrational colonial boundaries.

(13) This means, according to Griggs (1997: 64), after independence African countries agreed to stick with colonial boundaries which were the result of the 1884 Berlin Conference. Herbst (1989: 673) argues: "there is widespread agreement that the boundaries are arbitrary, yet the vast majority of them have remained virtually untouched since the late 1800's, when they were first demarcated. "The only two exceptions are Eritrea and the Western Sahara.

(14) Griggs (1997: 66) argues that African colonial boundaries are also the causes for high economic costs. That is to say, due to border disputes African countries purchase armaments and sometimes the expense is equivalent to the foreign aid they are receiving.

(15) E.g., the relation between the ancient Axumite Kingdom of Ethiopia and the Meroe Kingdom of Sudan.

(16) Egypt annexed Sudan in 1821-1822.

(17) Named after their leader Muhammad Ahmad ("Mahdi") who later ruled Sudan from June 1881 to June 1885 by expelling the Anglo-Egyptian forces.

(18) The Mahdists successfully expelled the Egyptians from Sudan and occupied Khartoum in 1885.

(19) Khalifa Abdallah succeeded Mahdi and ruled Sudan from June 1885 to September 1898.

(20) According to Abdussamad (1999), "Towards the end of the nineteenth century, the Ethiopian empire incorporated the north western border enclaves of Bela-Shangul and Gumuz into greater Ethiopia."

(21) Major Charles Gwynn (Later Major General) was born in Ireland in 1870. In 1889, he was commissioned in the Royal Engineers. He joined the geographical section of the Intelligence Branch of the war office from 1897 to 1901. Until 1904 he undertook survey work in the Sudan. He was awarded his CMG for conducting the survey determining the border between Ethiopia and Sudan $\mathrm{He}$ died in 1963 in Dublin, Ireland (Long 1983). 
(22) Gwynn uses the terms "Abyssinia" and "Abyssinians" throughout his article.

(23) This is because either the Europeans were not affordable or the Ethiopians were not ready to trust them (Gwynn 1937: 150).

(24) The forces of Khalifa were able to push the British forces towards Gedaref and Gallabat provinces and Blue Nile and Sobat rivers (Gwynn 1937: 151)

(25) Named after the head of the delegation, James Rennell Rodd.

(26) By that time, the British themselves had no clear information about the Ethiopia-Sudan border areas. According to Gwynn (1937: 150-151), "to take the case of the Sudan; the maps in much of the frontier regions were blank, and other parts were out of date-nor could the Abyssinians supply reliable information".

(27) As I stated earlier, the Dervishes defeated the Anglo-Egyptian forces in 1885 and drove them from cities like Khartoum. However, in July 1894, the Italians under General Baratieri expanded their holding from Massawa and conquered Kassala from the Dervishes. When the Italians were defeated by Menelik of Ethiopia in 1896 at Adwa, they were not in a position to maintain their forces in Kassala though the post Adwa peace agreement between Ethiopia and Italy allow the latter to keep its military presence in the Kassala area (The New York Times 21 December 1897). In the mean time, the Dervishes besieged the Italian forces at Kassala in March 1896. Unable to resist the pressure, the Italians decided to evacuate from Kassala, and the Anglo-Ethiopian forces rapidly occupied Kassala. The British used Kassala as a launching pad to counter-attack the Dervishes who fortified themselves in Khartoum (The New York Times 21 December 1897).

(28) Captain Bright had previously conducted an expedition from East Africa to the northern end of Lake Rudolf

(29) Elaboration is mine

(30) In the following years, some of the communities resisted the British's attempt to put them in Sudan. One of the leaders of the resistance was Ibrahim Wad Mahmud. Then, the British sent an army to crush the resistance and hanged Ibrahim Wad Mahmud in Khartoum (See Gwynn 1937: 154).

(31) As testified by Mburu (2003:20) "Addis Ababa renounced Britain's attempt to rectify this border through a survey by Major Charles Gwynn (Royal Engineers) in August 1908 for excluding Ethiopian surveyors." 
(32) The preliminary survey of the Kenya-Ethiopia boundary was earlier carried out by Captain P. Maud R.E., in the winter of 1902-1903. He surveyed the area between the Dawa River and Lake Rudolf (Gwynn 1937: 159).

(33) Emperor Menelik's illness was a great concern for the British as clearly seen in the British newspapers. The New York Times reported the health condition of the Emperor on almost regular basis (See: New York Times 9 January 1992; 30 January 1909; 2 November 1909; 1 December 1906; 23 December 1906; 25 May 1910; 22 February 1910; 29 March 1910; 31 October 1909; 12 January 1910; 2 April 1910; 19 December 1909).

(34) One of the causes for the conflict between Ethiopia and Sudan was a boundary problem. In order to properly study his country's boundary problem with Sudan Haile Selassie established two inquiry committees at different times.

(35) VOA (05 June 2008) reported that, "The news of a boundary settlement shocked many Ethiopians, who consider the ceded Ethiopian land to be historically and culturally theirs."

(36) As reported by Arabic News.com (7-3-2003), Ethiopia (under the direct order of Prime Minister Meles Zenawi) agreed to return the lands in al-Fashqa area to the east of "Sundus" and Atbarawi River, except small pockets of lands which were not settled yet. According to the claim of Abdul Rahman al-Khuder, the Wali ("governor") of al-Qadaref province, after a series of negotiations "direct directions were issued by the Ethiopian Prime Minister Meles Zenawi to end the conflict which lasted for 7 years and the return of the lands to its Sudanese owners. "In the border negotiations, according to Abdelrahman al-Khidir Sudan has got 17 Sudanese villages from Ethiopia which were the "Source of dispute for more than 100 years" between Sudan and Ethiopia (Sudan Tribune 4 July 2007).

\section{REFERENCES}

ABBINK, JON (2003): "Badme and the Ethio-Eritrean border: The challenge of demarcation in the post-war period". Africa [Rome]LVIII, (2) (Jun): 219-31.

ABBINK, J (1998): "Briefing: The Eritrean-Ethiopian Border Dispute", African Affairs 97(389), 551-565.

ABDUSSAMAD H. AHMAD (1999): "Trading in Slaves in Bela-Shangul and Gumuz, Ethiopia: Border-Enclaves in History 1897-1938", In: The Journal of African History, 40, pp. 433-446.

AGHEMELO, A. T., AND S. IBHASEBHOR (2006): Colonialism as a Source of Boundary Dispute and Conflict among African States: The World Court 
Judgment on the Bakassi Peninsula and its Implications for Nigeria, Journal of Social Sciences. 13(3): 177-181.

AJALA, ADEKUNLE (1983): "The Nature of African Boundaries." Afrika Spectrum, 18: 177-188.

AKIHIRO, IWASHITA (2005): "An Inquiry for New Thinking on the Border Dispute: Backgrounds of "Historic Success" for the Sino-Russian Negotiations", in: Siberia and the Russian Far East in the $21^{\text {st }}$ Century: Partners in the "Community of Asia", (Iwashita A. Akihiro (Ed.), vol. 1, Chapter 6, pp. 95-115.

ADLER, R. (1995): 'Positioning and Mapping International Land Boundaries.' In: Boundary and Territory Briefing, Clive Schofield and Peter Hocknell (Eds.), International Boundaries Research Unit, Durham: University of Durham, vol. 2, No.1, pp. 1-40.

ANDERSON, MALCOLM (1996): Frontiers: territory and state formation in the modern world. Cambridge: Polity Press. http://www.issi.org.pk/journal/2004_files/no_2/article/7a.htm, (Retrieved on 10April 2008).

ARABIC NEWS.COM (7-3-2003): "Sudan, Ethiopia end border dispute." http://www.arabicnews.com/ansub/Daily/Day/030703/2003070305.html, (Retrieved on 6/29/2008).

ASIWAJU, A.I. (1984): "Artificial Boundaries." Inaugural Address, University of Lagos: Lagos, 12 December.

ASIWAJU, A.I. (1985): "The Conceptual Framework." In: Partitioned Africans, ed. A. I. Asiwaju. New York: St. Martin's Press, 1-18.

ASIWAJU, A. I., PAUL NUGENT (1993): « The Paradox of African Boundaries. » in African Boundaries: Barriers, Conduits and Opportunities. A. I. Asiwaju and Paul Nugent (eds.) London: Pinter.

ATZILI, BOAZ (2004): Good Fences Can Make Bad Neighbors: State Weakness, Border Fixity, and the War in Congo. A Paper prepared for delivery at the International Studies Association conference in Montreal, Canada, March 17-20, 2004.

BACH, DANIEL (Ed.). (1999): Regionalisation in Africa: Integration and Disintegration. Bloomington: Indiana University Press.

BAHRU ZEWDE (2002): A History of Modern Ethiopia 1855-1991. Addis Ababa.Addis Ababa University Press, $2^{\text {nd }}$ edition. 
BARBOUR, K.M. (1961): "A Geographical Analysis of Boundaries in InterTropical Africa." In: Essays on African Population, ed. K.M. Barbour and R.M. Prothero. London: Routledge and Kegan Paul, 303-323.

BELLO, ADEBAYO (1995): "The Boundaries Must Change." West Africa, 10 April: 546.

BERRY, L, (1968): The Sudan's Contact with East Africa, International Conference on Sudan in Africa, University of Khartoum- Faculty of Arts Sudan Research Unit.

BENTSI-ENCHILL, KWAMENA (1976): "The Traditional Legal Systems of Africa," Property and Trust, vol. 6, International Encyclopedia of Comparative Law. Tubingen, Germany: J. C. B. Mohr, 2-38.

BLAKE, GERALD (April 1995): "The Depiction of International Boundaries on Topographic Maps," IBRU Boundary and Security Bulletin.

BOUQUET, CHRISTIAN (2003): Artificiality of the borders in sub-Saharan Africa. Cahiers d'Outre-Mer56, (222) (Apr-Jun): 181-98.

BRAMBILLA, CHIARA (n.d): Borders and Identity: The Cartographic Invention of the Ghana/Togo Boundary and the Ewe Identity. Università degli Studi di Bergamo.

BROWN, HARRY (October 1994): The Iraq-Kuwait Boundary Dispute: Historical Background and the UN Decisions of 1992 and 1993," IBRU Boundary and Security Bulletin.

BROWNLIE, IAN (1979): African Boundaries: A Legal and Diplomatic Encyclopedia. London: C. Hurst and Company.

CAFLISCH, LUCIUS (2006): "A Typology pf Borders," International Symposium on Land and River Boundary Demarcation and Maintenance in Support of Borderland Development Bangkok, 7-9 November 2006.

CLAPHAM, CHRISTOPHER (1996): Africa and the International System. Cambridge: Cambridge University.

DAVIDSON, BASIL (1992): The Black Man's Burden: Africa and the Curse of the Nation-State. New York: Times Books.

DECAPUA, JOE (11 June 2008): "Djibouti-Eritrean Clash Called Minor Incident, But Adds to Regional Volatility," VOA.

DEUTSCHE WELLE (08-05-2008): "Sudan keethiopia meret silemagnetua" ("About Sudanese Acquisition of Land from Ethiopia" 
DFID (Department for International Development) (October 2001): "The causes of conflict in Sub-Saharan Africa: Framework Document' Foreign and Commonwealth Office; London.

DZUREK, DANIEL J. (Spring 1996): Eritrea-Yemen Dispute over the Hanish Islands, IBRU, Boundary and Security Bulletin.

DZUREK, DANIEL J. (Spring 1999): "Gulf of Guinea Boundary Disputes" IBRU Boundary and Security Bulletin.

DZUREK, DANIEL J. (Winter 1999-2000): "What Makes Some Boundary Disputes Important?" IBRU Boundary and Security Bulletin, 83-95.

ENGLEBERT, PIERRE, STACY TARANGO AND MATTHEW CARTER (February 2001): "Dismemberment and Suffocation: A Contribution to the Debate on African Boundaries." Pomona College. http://www.politics.pomona.edu/penglebert/borders_FINAL.pdf, (Retrieved on 6 September 2008)

ENGLUND, H. (2003): From war to peace on the Mozambique Malawi borderland. Journal of the Royal Anthropological Institute 9, (2) (Jun): 361-2.

FIELDING, MARGARET (Spring 1999): Bad Times in Badme: Bitter Warfare Continues Along the Eritrea-Ethiopia Border. IBRU Boundary and Security Bulletin.

FOUCHER, MICHEL (1991): Fronts et frontières. Un tour du monde géopolitique. Paris: Fayard. Griffiths, leuan (1996): "Permeable Boundaries in Africa." In African Boundaries, ed. Paul Nugent and A.I. Asiwaju. London: Pinter, 68-83.

GRIGGS, R. A. (1995b): 'African Boundaries -Reconsidered,' Internationales Afrikaforum, 31, 1: 56-62.

GRIGGS, R. A. (1994): 'Boundaries for a New Africa,' Track Two, 3, 4: 9-12, December 1994.

GRIGGS, R. A. (1995a): 'Boundaries and War in Africa in 1995,' IBRU Boundary and Security Bulletin, 3, 1: 77-80.

GRIGGS, RICHARD A. (Summer 1997): The Boundaries of an African Renaissance. IBRU Boundary and Security Bulletin, pp. 64-68.

GWYNN, CHARLES (1937): "The Frontiers of Abyssinia: A Retrospect", In: African Affairs, XXXVI, 150-161. 
HERBST, JEFFREY (2000): States and Power in Africa: Comparative Lessons in Authority and Control. Princeton: Princeton University Press.

HERBST, JEFFERY (1989):"The Creation and Maintenance of National Boundaries in Africa." International Organization 43, no. 4 (Autumn 1989): 673.

HOILE, DAVID (May 2002): The European-Sudanese Public Affairs Council "The Search for Peace in the Sudan: A Chronology of the Sudanese Peace Process 1989-2001" The European-Sudanese Public Affairs Council, London.

Hoyle, Peggy (Autumn 2000): Somaliland: Passing the Statehood Test? IBRU Boundary and Security Bulletin.

ICG (4 April 2002): Central Asia: Border Disputes and Conflict Potential, ICG Asia Report $\mathrm{N}^{\circ} 33$, Osh/Brussels.

JACKSON, ROBERT H. AND CARL G. ROSEBERG (1982): "Why Africa's Weak States Persist: The Empirical and the Juridical in Statehood." World Politics 35: 1-24.

JONES, S. B. (1945): Boundary Making, Washington: Carnegie Foundation for International Peace.

KAPIL, RAVI L. (1966): "On the conflict potential of Inherited Boundaries in Africa", World Politics, 18 (4), 656-673.

KORNPROBST, M. (2002): "The Management of Border Disputes in African Regional Sub-Systems Comparing West Africa and the Horn of Africa", The Journal o Modern African Studies, 40, pp. 369-393.

KONINGS, PIET (2005): The anglophone cameroon-nigeria boundary: Opportunities and conflicts. African Affairs 104, (415) (Apr): 275-301.

KORKOR, FRANCIS O. (2001): The Surveyor and the Boundary: A Spatial Odyssey : 42nd Australian Surveyors Congress. http://www.isaust.org.au/innovation/2001-Spatial_Odyssey/pdf/korkor.pdf, (Retrieved on 6 September 2008).

KROMM, DAVID K. (1967): "Irrendentism in Africa: The Somali-Kenya Boundary Dispute", Transactions of the Kansas Academy of Science, 70(3), 359-365.

KRUKOSKI, WILSON R.M. (n.d):'Frontiers and Boundaries', (Translated by Jose A. Krukoski), <http://www.info.Incc.br/wrmkkk/artigoi.html> (Retrieved on 15 June 2008). 
KUM, JOSEPH M. (1993): "The Central African Subregion." Disarmament: Workshop on the Role of Border Problems in African Peace and Security. New York: United Nations, 1993, 49-71.

KWIATKOWSKA, BARBARA (2001): The Eritrea/Yemen Arbitration: Landmark Progress In The Acquisition of Territorial Sovereignty and Equitable Maritime Boundary Delimitation. Ocean Development and International Law, 32(1).

LENTZ, CAROLA (2003): 'This is Ghanaian territory!' land conflicts on a West African border. American Ethnologist 30, (2) (May): 273-89.

LOISEL, SÉBASTIEN (2004): The European Union and African Border Conflicts: Assessing the Impact of Development Cooperation. UACES Student Forum Regional Conference, Cambridge, May 7th 2004.

LONG, GAVIN (1983):'Gwynn, Sir Charles William (1870 - 1963)', Australian Dictionary of Biography, Volume 9, Melbourne University Press, pp 146-147.

MAYALL, JAMES (1973): "The Malawi-Tanzania Boundary Dispute" The Journal of Modern African Studies, 11 (4), 611-628.

MBURU, NENE (22 March 2003): "Delimitation of the Elastic Ilemi Triangle: Pastoral conflicts and official Indifference in the Horn of Africa." African Studies Quarterly, vol.7.

MILES, WILLIAM F.S. (1994): Hausaland Divided: Colonialism and Independence in Nigeria and Niger. Ithaca: Cornell University Press.

MWAURA, PETER (16 July 2005): “Kenya's Claim over Sudan, Ethiopia border Triangle Precarious," The Daily Nation.

MUGABI, FRANK (13 May 2008): "Uganda: Congo Yet to Leave Disputed Area”, New Vision (Kampala). Retrieved from <:http://allafrica.com/stories/200805140091.html> (Retrieved on 6/17/2008).

THE NEW YORK TIMES (17 February 1888): "A battle in Abyssinia."

THE NEW YORK TIMES (22 February 1910): "Accused by Menelik's Wife."

THE NEW YORK TIMES (7 March 1897): Britain's aim in Abyssinia."

THE NEW YORK TIMES (28 September 1897): "British to occupy Kassala: Italy completed Arrangements for ceding the Abyssinian Town."

THE NEW YORK TIMES (12 January 1898): "British Treaty with Menelik: Frontier Rectification Promised when the Khalifa is Subdued." 
THE NEW YORK TIMES (21 July 2008): "China says Russia will return disputed border land."

THE NEW YORK TIMES (31 October 1909): “Expect Menelik to die.”

THE NEW YORK TIMES (4 April 1889): "King John Reported Dead."

THE NEW YORK TIMES (4 May 1889): “King John's Death.”

THE NEW YORK TIMES (25 September 1898): "Menelik and His Empire: Wise and peaceful Monarch."

THE NEW YORK TIMES (29 March 1910): "King Menelik not dead."

THE NEW YORK TIMES (1 December 1906): "King Menelik Seriously ill."

THE NEW YORK TIMES (2 November 1909): "Menelik is Daying"

THE NEW YORK TIMES (9 January 1912): "Menelik is Paralized."

THE NEW YORK TIMES (2 April 1910): "Menelik may be alive."

THE NEW YORK TIMES (19 December 1909): "Hears Menelik is Dead."

THE NEW YORK TIMES (23 December 1906): "Menelik Again ill.”

THE NEW YORK TIMES (6 September 1910): "Menelik again rallies."

THE NEW YORK TIMES (23 January 1898): "Menelik Mobilizing his army: Explanation Given for the Rush of British Troops to Egypt."

THE NEW YORK TIMES (30 January 1909): "Menelik really ill."

THE NEW YORK TIMES (23 May 1897): "Menelik to help the Dervishes."

THE NEW YORK TIMES (12 January 1910): "Menelik Reported Dead."

THE NEW YORK TIMES (25 May 1910): "Menelik reported dying."

THE NEW YORK TIMES (21 December 1897): "Ready to Transfer Kassala."

THE NEW YORK TIMES (20 February 1888): "The Abyssinian Defeat".

THE NEW YORK TIMES (16 January 1902): "To explore the Sobat region: W.Fitz Hugh Whitehouse, Jr., and Lord Hindlip Going to Abyssinia." 
THE NEW YORK TIMES (22 September 1897): "Treaty with Mahdi: King Melelik's frontier Guaranteed by Great Britain and the Mahdi, according to the Figaro."

THE NEW YORK TIMES (25 July 1884): "With the King of Abyssinia."

NKIWANE, SOLOMON M. (1993): "Southern Africa." Disarmament: Workshop on the Role of Border Problems in African Peace and Security. New York: United Nations, 29-37.

NORDQUIST, KJELL-AKE (2002): Boundary Conflicts and Preventive Diplomacy, Chapter 2, Carnegie Commission on preventive Deadly conflict. <http://wwics.si.edu/subsites/ccpdc/pubs/zart/ch2.htm> (Retrieved on 5 September 2008).

NUGENT, P. AND ASIWAJU, A. I. (1996): African boundaries: Barriers, conduits and opportunities. London: Pinter.

NUGENT, PAUL (1996): "Arbitrary Lines and the People's Minds: A Dissenting View on Colonial Boundaries inWest Africa." In: African Boundaries, ed. Paul Nugent and A.I. Asiwaju. London: Pinter, 35-67.

NUGENT, PAUL AND A.I. ASIWAJU (1996): "Introduction: The Paradox of African Boundaries." In: African Boundaries, ed. Paul Nugent and A.I. Asiwaju. London: Pinter, 1-17.

ODUGBEMI, SINA (1995): "Consensus and Stability." West Africa. 3 April: 501503.

ODUNTAN, GBENGA (2006): The demarcation of straddling villages in accordance with the International court of justice jurisprudence: The Cameroon -- Nigeria experience. Chinese Journal of International Law 5, (1) (Mar): 79-114.

OTTAWAY, MARINA (1999): "Keep Out of Africa." Financial Times. 25 February.

ÖZCAN, MESUT (2002): "Border Concept and Turkey-Iraq Border," Turkish Review of Middle East Studies, no.13, pp.41-85.

PEARCE, JUSTIN (May-June 2000): Facts on the Ground: War and Peace in the Horn of Africa, IBRU Boundary and Security Bulletin.

PERRY, ALAN (Summer 2000): Caprivi Strip: World Court Awards Island To Botswana: International Court of Justice Case concerning Kasikili/Sedudu Island (Botswana/Namibia). IBRU Boundary and Security Bulletin, pp.80-87. 
PRATT, MARTIN (2006): A terminal crisis? Examining the breakdown of the Eritrea - Ethiopia Boundary Dispute Resolution process. Conflict Management and Peace Science 23, (4) (winter): 329-41.

PRESCOTT V. (1979): 'Africa's Boundary Problems', Optima, 28, 1.

PRESCOTT, J.R.V. (1987): Political Frontiers and Boundaries, London: Allen and Unwin.

RANKIN, KJ AND R SCHOFIELD (2004): "The Troubled Historiography of Classical Boundary Terminology," Mapping Frontiers, Plotting Pathways: Ancillary Paper, No. 2.

RUBENSON, SECEN (1976): The Survival of Ethiopian Independence, London.

RUSHWORTH, DENNIS (Spring 1997): "Mapping in Support of Frontier Arbitration: Delimitation and Demarcation." IBRU Boundary and Security Bulletin, pp.61-64.

SAMBANIS, NICHOLAS (1999): "Partition as a Solution to Ethnic War: An Empirical Critique of the Theoretical Literature." World Politics 52: 437-483.

SANDERSON, G.N. (1969): Conflict and Cooperation between Ethiopia and the Mahdist State, In Sudan Notes and Records, Vol. 50, Khartoum.

SAUTTER, GILLES (1982): "Quelques réflexions sur les frontières africaines" in Catherine Coquery-Vidrovitch (Ed.). Problèmes frontières dans le Tiers-Monde. Paris: Université de Paris.

SHAW, MALCOLM (1997): "People, Territorialism and Boundaries", In: European Journal of International Law, Vol. 8, No. 3, pp. 478-507.

SMITH, BARRY (1995):'On Drawing Lines on a Map', A. U. Frank, W. Kuhn and D. M. Mark (eds.), Spatial Information Theory. Proceedings of COSIT '95, Berlin/Heidelberg/Vienna/New York/London/Tokyo: Springer Verlag, 1995, 475484.

SODEINDE, OLALEKAN RASHEED (2001): Boundary Conflict Resolution through the Spatial Analysis of Social, Commercial and Cultural Interaction of People Leaving Along Boundary Area. International Conference on Spatial Information for Sustainable Development, Nairobi, Kenya, 2-5 October 2001.

SUDAN TRIBUNE (4 July 2007): "Eastern Sudan farmers get back disputed land from Ethiopia."

TIME (3 July 1995): "Sudan Threatens to Block the Nile." 
TOUVAL, SAADIA (1969): "The Sources of Status Quo and Irredentist Policies." In African Boundary Problems, ed. Carl Gosta Widstrand. Uppsala: The Scandinavian Institute of African Studies, 101-118.

UNHCR (16 January 2006): Sudan Operations: Sudan/Chad Situation update 44.

VOA (05 June 2008): "Border Demarcation with Sudan Caused Anger in Ethiopia."

VOA (11 June 2008): "Djibouti Says Two Dead in Eritrea Border Clash."

WEMBOU, MICHEL-CYR D. (1994): "The OAU and International Law." In: The Organization of African Unity after Thirty Years, (ed.) Yassin El-Ayouty, London: Praeger.

WESTING, ARTHUR H. (1996): "The Eritrean-Yemeni Conflict over the Hanish Archipelogo: Toward a Resolution Favoring Peace and Nature", Security Dialogue 27(2), 201-206.

YACOB ARSANO (2007): Ethiopia and the Nile Dilemmas of National and Regional Hydropolitics. Center for Security Studies, Swiss Federal Institute of Technology, Zurich.

YOUNG, CRAWFORD (1996): "The Impossible Necessity of Nigeria: A Struggle for Nationhood," Foreign Affairs, November/December, 75(6):139-143.

YOUNG, JOHN (2007): "Armed Groups along Sudan's Eastern Frontier: An Overview and Analysis, "Small Arms Survey, Graduate Institute of International Studies, Geneva 